\title{
P2Y2 receptor promotes the migration and invasion of breast cancer cells via EMT-related genes Snail and E-cadherin
}

\author{
YING QIU $^{1,3^{*}}$, YAN LIU $^{1 *}$, WEI-HUA LI ${ }^{1}$, HONG-QUAN ZHANG ${ }^{2}$, XIN-XIA TIAN $^{1}$ and WEI-GANG FANG ${ }^{1}$ \\ ${ }^{1}$ Department of Pathology, Key Laboratory of Carcinogenesis and Translational Research (Ministry of Education), \\ School of Basic Medical Sciences, and ${ }^{2}$ Department of Anatomy, Histology and Embryology, \\ Peking University Health Science Center, Beijing 100191; ${ }^{3}$ Department of Pathology, \\ Linyi People's Hospital, Linyi, Shandong 276000, P.R. China
}

Received May 19, 2017; Accepted October 13, 2017

DOI: $10.3892 /$ or.2017.6081

\begin{abstract}
Adenosine 5'-triphosphate (ATP) is one of the most abundant biochemical constituents within the tumor microenvironment and is postulated to play critical roles in the progression of a number of types of tumors via interaction with the P2Y2 receptor. In the present study, we demonstrated that the P2Y2 receptor was highly expressed in MCF7 and Hs578T breast cancer cells. Downregulation of the P2Y2 receptor by small interfering RNA (siRNA) significantly attenuated ATP- or UTP-driven migration and invasion of the breast cancer cells as well as expression of EMT-related genes Snail and E-cadherin. Consistent with the observations in vitro, the P2Y2 receptor was found to be abundantly expressed at the invasive edge of the tumor, in infiltrating tumor cells in breast adipose tissues and/or the cancer embolus in the lymphatic sinuses compared with the tumor core areas. Furthermore, high Snail expression and weak or negative expression of E-cadherin were observed at the invasive edge of tumors. Taken together, these data indicate that the P2Y2 receptor promoted cell migration and invasion in breast cancer cells via EMT-related genes Snail and E-cadherin.
\end{abstract}

\section{Introduction}

Breast cancer is one of the most common malignancies affecting women worldwide, and is the second leading cause of cancer-related death among women worldwide (1). Although early detection and extensive use of adjuvant therapies have greatly reduced patient mortality, tumor invasion and

Correspondence to: Professors Wei-Gang Fang or Xin-Xia Tian, Department of Pathology, School of Basic Medical Sciences, Peking University Health Science Center, Beijing 100191, P.R. China

E-mail:wgfang@bjmu.edu.cn

E-mail: tianxinxia@163.com

${ }^{*}$ Contributed equally

Key words: $\mathrm{P} 2 \mathrm{Y} 2$ receptor, extracellular ATP, EMT, migration, invasion, breast cancer metastasis remain the most life-threatening aspects of breast cancer. Metastasis is a multistep process involving numerous interactions between a tumor and its microenvironment. Of the multiple biological cascades of metastasis, epithelialmesenchymal transition (EMT) is a critical process associated with increased aggressiveness, and is required for the initiation of the metastatic spread of tumor cells to distal tissues (2).

Since purinergic signaling was first proposed, extracellular adenosine 5'-triphosphate (ATP) and the receptors are emerging as novel and important modulators of inflammation, immunity and as such potential players in host-tumor interaction. In addition to its function as the main form of intracellular energy for all types of cells, ATP has been widely accepted as an extracellular signaling molecule, which can extracellularly be released under both physiologic and pathologic conditions $(3,4)$. It has been demonstrated that a high concentration of extracellular ATP, in the hundreds micromolar range, is present in tumors, particularly in the vicinity of necrotic areas $(5,6)$, whereas it is basically undetectable in normal tissues (4), indicating that ATP acts as a stimulus in cancer progression. As a ubiquitous extracellular messenger, ATP functions through purinergic receptors, which are divided into two distinct families: ligand-gated cation permeable channel $\mathrm{P} 2 \mathrm{X}$ receptors and $G$ protein-coupled $P 2 Y$ receptors. Currently, 7 subtypes of the $\mathrm{P} 2 \mathrm{X}$ family (P2X1-7) and 8 subtypes of the P2Y family (P2Y1, P2Y2, P2Y4, P2Y6, P2Y11, P2Y12, P2Y13 and P2Y14) have been cloned and functionally characterized (7).

ATP-induced purinergic signaling has been implicated in many biological processes such as neurotransmission, muscle contraction, cell proliferation, differentiation, migration and apoptosis (7). Different P2Y receptor subtypes have been identified to be expressed in several types of cancer in both primary samples of human cancer tissues and cell lines (8). Our previous studies revealed that ATP enhanced the in vitro invasion of prostate cancer cells via P2Y receptors $(9,10)$. Subsequently, we demonstrated that the $\mathrm{P} 2 \mathrm{Y} 2$ receptor is one of the critical receptors which mediate ATP-promoted invasion and metastasis of prostate cancer cells both in vitro and in vivo (11). As one of the $\mathrm{G}$ protein-coupled receptors, the $\mathrm{P} 2 \mathrm{Y} 2$ receptor was found to participate in transactivation of EGFR as well as increased activity of MAPK and PI3K signaling pathways in various cancer cells (12-14). Additionally, various 
studies have shown that the $\mathrm{P} 2 \mathrm{Y} 2$ receptor is overexpressed in colon cancer and was involved in the metastasis of colorectal cancer cells in a mouse model $(15,16)$. All of these studies strongly suggest a critical role of the P2Y2 receptor in cancer progression. In the present study, we aimed to investigate the function of the P2Y2 receptor in extracellular ATP-regulated migration and invasion, and the underlying mechanisms in breast cancer progression.

\section{Materials and methods}

Chemicals and antibodies. ATP and UTP were purchased from Sigma (St. Louis, MO, USA) and dissolved in $\mathrm{ddH}_{2} \mathrm{O}$ to a concentration of $100 \mathrm{mM}$. The antibodies of P2Y1 (H-120), P2Y2 (H-70), P2Y4 (H-60), P2Y6 (H-70), Snail (H-130), E-cadherin (G-10) and $\beta$-actin were purchased from Santa Cruz Biotechnology (Santa Cruz, CA, USA). Absolute ethyl alcohol, dimethyl benzene, formaldehyde and hydrogen peroxide were purchased from Beijing Chemical Works (Beijing, China).

Breast tissues and clinical information. Tumor samples were collected from 198 patients who were diagnosed with breast carcinoma and who underwent modified radical mastectomy between 2006 and 2010 at Peking University Third Hospital. Among the 198 patients (median age, 51 years; range, $21-79$ years), 148 patients $(74.7 \%$ ) had invasive ductal carcinomas. Tumor characteristics and lymph node status were retrieved from the pathology reports and various clinical data were gathered. The tumor staging was defined according to the American Joint Committee on Cancer (AJCC) Tumor-Node-Metastasis (TNM) Staging System for Breast Cancer. Histological grading of tumors was performed according to the Nottingham (Elston-Ellis) modification of the Scarff-Bloom-Richardson grading system (17). The Nottingham Prognostic Index (NPI) was calculated as follows: Lymph node (LN) stage (negative nodes, 1 point; 1-3 positive nodes, 2 points; $\geq 4$ positive nodes, 3 points) + Grade (1-3) + Maximum diameter $(\mathrm{cm}) \times 0.2$. A pevious study divided the patients into 3 NPI groups: a good prognostic group with an observed NPI range of 2-3.4, a moderate prognostic group with an index range of 3.4-5.4, and a poor prognostic group with an NPI $\geq 5.4$ (18). Detailed descriptions of the histological assessment, including nodal status, histological grade and type, NPI grouping, estrogen receptor (ER) and HER2 amplification status are presented in Table I.

Cell lines and culture conditions. The MCF7 and Hs578T human breast cancer cell lines were purchased from the American Type Culture Collection (ATCC; Manassas, VA, USA). The MCF7 breast cancer cells were cultured in RPMI-1640 medium (Gibco, Grand Island, NY, USA) supplemented with $10 \%$ fetal bovine serum (FBS). The Hs578T cells were cultured in Dulbecco's modified Eagle's medium (DMEM) (Gibco) containing 10\% FBS. The cells were grown in a humidified atmosphere containing $5 \% \mathrm{CO}_{2}$ at $37^{\circ} \mathrm{C}$.

Reverse transcription and real-time PCR. Total RNA was extracted using TRIzol reagent (Invitrogen, Carlsbad, CA, USA), and $2 \mu \mathrm{g}$ of total RNA was reversely transcribed into cDNA using Moloney Murine Leukemia Virus (MMLV)
Table I. Statistical analysis of the expression of the P2Y2 receptor (mean $\pm \mathrm{SD}$ ) and clinicopathological characteristics of the breast cancer cases.

\begin{tabular}{|c|c|c|c|}
\hline Characteristics & $\mathrm{N}$ & $\mathrm{P} 2 \mathrm{Y} 2$ & P-value \\
\hline Grade & & & $0.023^{\mathrm{a}}$ \\
\hline 1 & 36 & $6.49 \pm 2.58$ & \\
\hline 2 & 122 & $6.26 \pm 2.05$ & \\
\hline 3 & 38 & $4.77 \pm 1.70$ & \\
\hline TNM stage & & & $0.511^{\mathrm{b}}$ \\
\hline $\mathrm{I}+\mathrm{II}$ & 134 & $6.11 \pm 2.24$ & \\
\hline $\mathrm{III}+\mathrm{IV}$ & 63 & $5.80 \pm 2.92$ & \\
\hline $\begin{array}{l}\text { Lymph node } \\
\text { metastasis }\end{array}$ & & & $0.407^{\mathrm{b}}$ \\
\hline Yes & 116 & $6.17 \pm 2.03$ & \\
\hline No & 81 & $5.79 \pm 2.29$ & \\
\hline Distant metastasis & & & $0.360^{\mathrm{b}}$ \\
\hline Yes & 28 & $6.53 \pm 2.70$ & \\
\hline No & 170 & $5.93 \pm 2.20$ & \\
\hline Location in the tumor & & & $0.020^{\mathrm{b}}$ \\
\hline Tumor core & 92 & $1.99 \pm 1.18$ & \\
\hline $\begin{array}{l}\text { Invasive edge or } \\
\text { cancer embolus }\end{array}$ & 92 & $2.48 \pm 1.63$ & \\
\hline NPI & & & $0.141^{\mathrm{a}}$ \\
\hline Good & 28 & $6.30 \pm 2.42$ & \\
\hline Moderate & 115 & $6.28 \pm 2.18$ & \\
\hline Poor & 52 & $5.28 \pm 2.82$ & \\
\hline ER expression & & & $0.755^{\mathrm{b}}$ \\
\hline Yes & 83 & $5.94 \pm 1.27$ & \\
\hline No & 104 & $6.09 \pm 2.08$ & \\
\hline HER2 amplification & & & $0.008^{\mathrm{a}}$ \\
\hline Yes & 76 & $5.27 \pm 2.03$ & \\
\hline No & 114 & $6.47 \pm 3.08$ & \\
\hline
\end{tabular}

${ }^{a}$ Means for one-way ANOVA; ${ }^{b}$ means for independent-samples t-test. TNM, tumor-node-metastasis, ER, estrogen receptor; NPI, Nottingham Prognostic Index.

reverse transcriptase (Promega, Madison, WI, USA), following the manufacturer's instructions. Real-time PCR was carried out using ABI StepOne Real-Time PCR System (Applied Biosystems, Foster City, CA, USA). Due to no introns in the subtypes of P2Y receptors, DNase (Promega) was used to totally eliminate DNA contamination in the total RNA before reverse transcription. The expression of the examined genes was normalized by $\beta$-actin. The specific primers were synthesized and purified by Invitrogen and are listed in Table II. The thermal cycle conditions were as follows: $10 \mathrm{~min}$ at $95^{\circ} \mathrm{C}$, 30 cycles of $15 \mathrm{~s}$ at $95^{\circ} \mathrm{C}$ and $1 \mathrm{~min}$ at $60^{\circ} \mathrm{C}$. The $2^{-\Delta \Delta \mathrm{Ct}}$ method was used for relative quantification as previously described (19).

Cell lysis and western blot analysis. Cell extracts were generated using RIPA buffer (Applygen Technologies Inc., Beijing, China) supplemented with protease inhibitors (Roche, 
Table II. Sequences of the primers used in the real-time qPCR experiments.

\begin{tabular}{lllc}
\hline Target & \multicolumn{1}{c}{ Forward primer sequence (5'-3') } & \multicolumn{1}{c}{ Reverse primer sequence (5'-3') } & Length (bp) \\
\hline E-cadherin & CTGGGCTGGACCGAGAGA & GAAGGTCAGCAGCTTGAACCA & 60 \\
Claudin-1 & TGAAGTGCTTGGAAGACGATG & GGCAACTAAAATAGCCAGACCT & 95 \\
IL-8 & ACTGAGAGTGATTGAGAGTGGAC & AACCCTCTGCACCCAGTTTC & 112 \\
Snail & AATCGGAAGCCTAACTACAGCG & GTCCCAGATGAGCATTGGCA & 147 \\
P2Y1 & GTGCTGGTGTGGCTCATTGT & TGGTGTCGTAACAGGTGATGGT & 100 \\
P2Y2 & GCTACAGGTGCCGCTTCAAC & AGACACAGCCAGGTGGAACAT & 170 \\
P2Y4 & GTGAGGTGGAGCTGGACTGTTG & GGTCGGAGGCGGAAGATGA & 136 \\
P2Y6 & CCACAGGCATCCAGCGTAAC & AGGAAGCCGATGACAGTGAGAG & 106 \\
P2Y11 & CCTTCTGTGTCCACCCTCTACTCT & AGTGCTCTTGGCGTCCTCTG & 113 \\
P2Y12 & CACTGCTCTACACTGTCCTGT & AGTGGTCCTGTTCCCAGTTTG & 190 \\
P2Y13 & CACTGCTCTACACTGTCCTGT & AGTGGTCCTGTTCCCAGTTTG & 134 \\
P2Y14 & TGGAGTGTCAGGATGGATATTCT & GTCACCAAGGATCTTGAAAGGAA & 124 \\
$\beta$-actin & GGATGCAGAAGGAGATCACTG & CGATCCACACGGAGTACTTG & 90 \\
\hline
\end{tabular}

Mannheim, Germany). The concentration of protein was determined using a BCA reagent (Applygen Technologies Inc.). Equal amounts of protein were separated by sodium dodecyl sulfate-polyacrylamide gel electrophoresis (SDS-PAGE) gel and transferred onto nitrocellulose membranes (BioRad, Hercules, CA, USA), which were incubated separately with primary antibodies against the P2Y2 receptor (1:500), E-cadherin (1:500), claudin-1 $(1: 1,000)$, Snail $(1: 1,000)$ and $\beta$-actin $(1: 1,000)$ at $4^{\circ} \mathrm{C}$ overnight. Immunoreactive proteins were visualized by chemiluminescence (Applygen Technologies Inc.) and quantified by densitometric analysis using Quantity One software (Bio-Rad).

siRNA and cell transfection. To investigate the role of the $\mathrm{P} 2 \mathrm{Y} 2$ receptor in ATP- and UTP-driven migration and invasion, two different small interfering RNAs (siRNAs) (siRNA1 and siRNA2) were used to downregulate the expression of the P2Y2 receptor in the breast cancer cells. MCF7 and Hs578T breast cancer cells were transfected with siRNAs directed against P2Y2 receptor (siRNA1 and siRNA2) gene expression or a scramble sequence not targeting any known gene as a control (NC). Two distinct siRNA oligonucleotides targeting the P2Y2 receptor were used with sequences as follows: P2Y2 siRNA1, 5'-GUGCUAACAGUUGCCUUGA-3' and P2Y2 siRNA2, 5'-GCCCAAGAGAUGAACAUCU-3'. A scramble siRNA was used as the negative control (NC). Cells were transfected with siRNA using Lipofectamine 2000 (Invitrogen) according to the manufacturer's instructions.

In vitro cell migration and invasion assays. The migration and invasion abilities of the breast cancer cells were evaluated using Boyden Chamber assay according to the method described by Albini et al (20), with some modifications. Cell migration capacity was analyzed using 24-well Transwell chambers which contained $8-\mu \mathrm{m}$ pore size polyethylene terephtalate membrane cell culture inserts. The upper compartment was seeded with $0.5 \times 10^{5}$ viable cells and the lower compartment was filled with $600 \mu 1$ NIH3T3 conditioned medium as a chemoattractant. After incubation with or without $100 \mu \mathrm{M}$ ATP for $12 \mathrm{~h}$ at $37^{\circ} \mathrm{C}$ in a humidified atmosphere containing $5 \% \mathrm{CO}_{2}$, the chambers were removed. Cells on the upper side of the chamber were removed with cotton-tipped swabs, and the cells on the lower surface of the membrane were fixed and stained with crystal violet. The number of migrated cells was counted under a light microscope at a magnification of $\mathrm{x} 200$. The average numbers of migrated cells were determined from 7 representative fields. Cell invasive ability was assessed using the same inserts as mentioned above, but with the membrane covered with a film of Matrigel (BD Biosciences, Franklin Lakes, NJ, USA). In this case, $1 \times 10^{5}$ viable cells were seeded in the upper compartment. Cells on the lower surface of the membranes were stained with crystal violet and observed under a microscope at a magnification of $\mathrm{x} 200$. The numbers of invaded cells in 7 fields were counted and the mean for each chamber was determined. Each experiment was repeated at least 3 times, and the results for migration and invasion were normalized to the controls.

Immunohistochemical staining. To further verify the role of the P2Y2 receptor in the invasion of breast cancer, immunohistochemical staining was carried out to detect the expression of $\mathrm{P} 2 \mathrm{Y}$ receptors and EMT protein markers in breast cancer tissue specimens with the avidin-biotin complex technique. Briefly, the slides were washed in xylene to remove the paraffin, rehydrated through serial dilutions of alcohol, followed by washings with a solution of phosphatebuffered saline (PBS) ( $\mathrm{pH}$ 7.2). Treated slides were then placed in a citrate buffer ( $\mathrm{pH}$ 6.0) and heated in a pressure cooker for $3 \mathrm{~min}$. The slides were then incubated overnight at $4^{\circ} \mathrm{C}$ with a series of anti-P2YR rabbit polyclonal antibodies including anti-P2Y1 (1:200 dilution), anti-P2Y2 (1:300 dilution), anti-P2Y4 (1:200 dilution) and anti-P2Y6 (1:400 dilution) antibodies, as well as anti-Snail rabbit polyclonal (1:200 dilution) and anti-E-cadherin mouse monoclonal antibodies (1:200 dilution), respectively. The Histostain-Plus Streptavidin-Peroxidase method (ZYMED kit 50-420Z; 
A
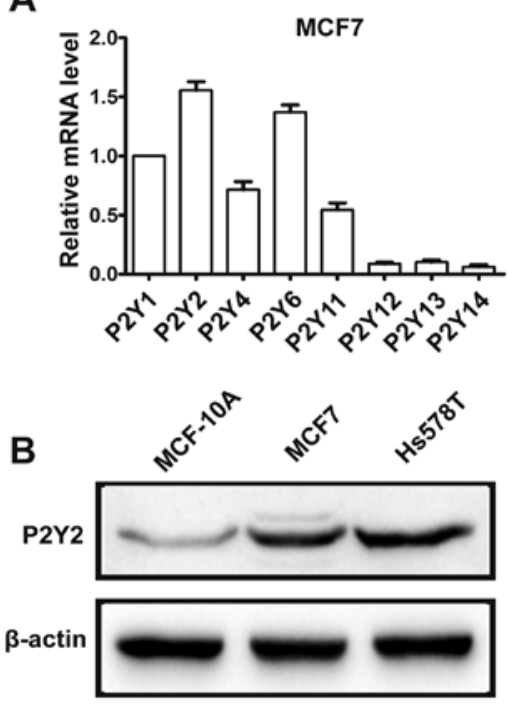
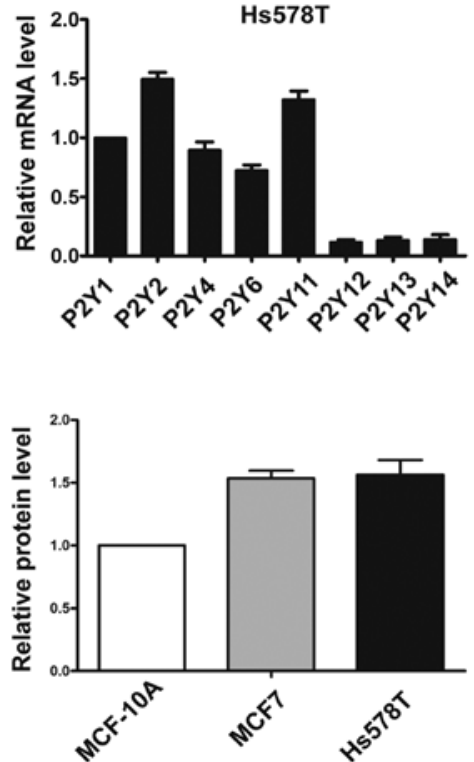

Figure 1. P2Y2 receptor is significantly expressed in breast cancer cells. (A) mRNA levels of P2Y receptor subtypes were detected by real-time PCR in MCF7 and Hs578T cells. The expression levels of all P2Y receptor subtypes were normalized to $\beta$-actin, and mRNA expression of the P2Y1 receptor was defined as 1 . (B) Protein level of the P2Y2 receptor in breast cancer cells was detected using western blot analysis. Results are demonstrated by histograms to quantify the expression levels. Data are presented as mean \pm SD (vertical bars). At least 3 independent experiments were performed.
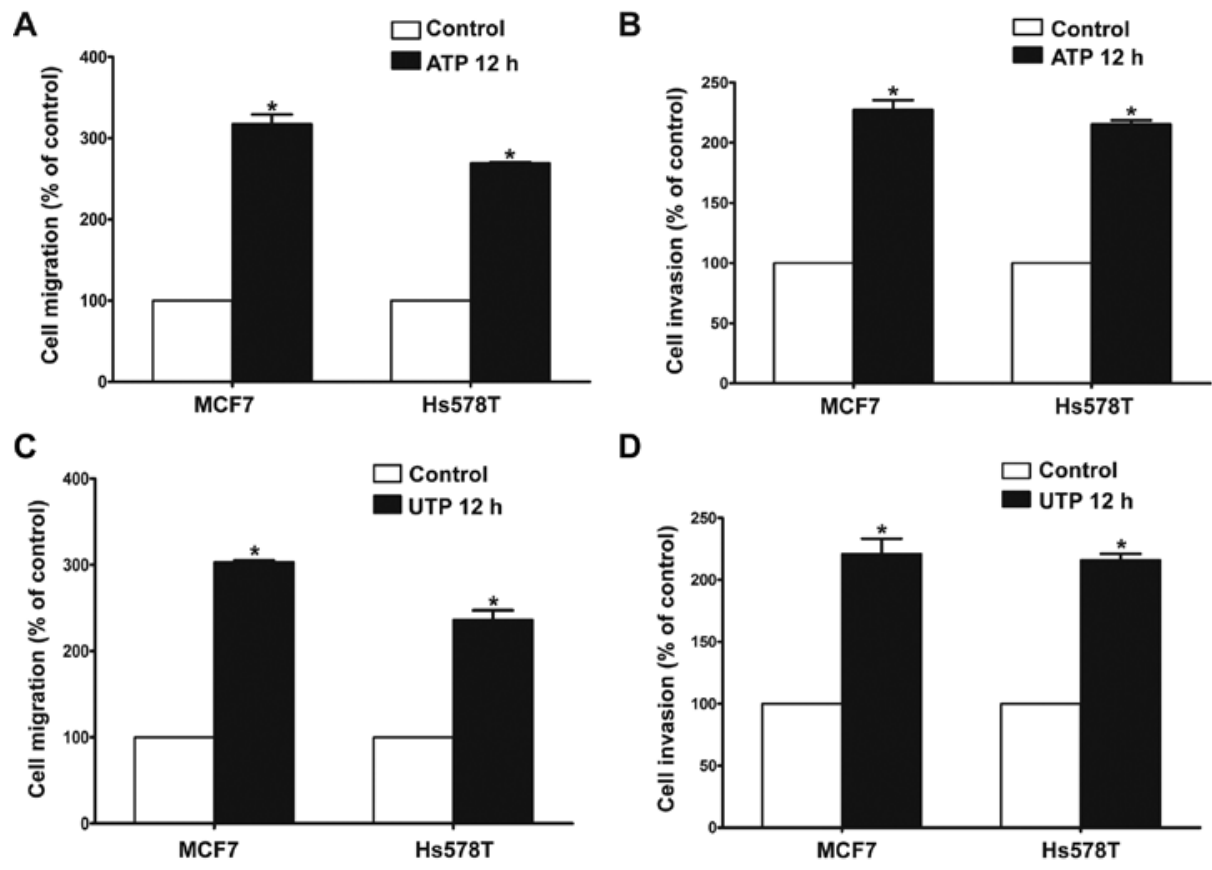

Figure 2. Effects of extracellular ATP or UTP on in vitro migration and invasion of breast cancer cells. (A and C) In vitro migration and (B and D) invasion assays were carried out as described in Materials and methods in the absence (control) or presence of $100 \mu \mathrm{M} \mathrm{ATP} / 100 \mu \mathrm{M}$ UTP for $12 \mathrm{~h}$ (ATP $12 \mathrm{~h} / \mathrm{UTP}$ $12 \mathrm{~h}$ ). Data of cell migration or invasion were calculated as a percentage of the control cells. Results are demonstrated by histograms and values are presented as mean $\pm \mathrm{SD}$ (vertical bars). At least 3 independent experiments were performed; ${ }^{*} \mathrm{P}<0.05$.

Life Technologies, Frederick, MD, USA) was performed for signal development and the cells were counterstained with hematoxylin. NCs were obtained by excluding the primary antibody. Slides were mounted with gum for examination and images were captured using an Olympus BX51 microscope (Olympus, Tokyo, Japan) and Nikon Digital Camera System for study comparison (Nikon, Tokyo, Japan).
Scoring of immunohistochemical stainings. We interpreted the cytoplasmic and/or nuclear staining as positive staining results. The German semi-quantitative scoring system, which has been widely accepted and used in previous studies (21), was also adopted to consider the staining intensity and area extent. Every tumor was scored according to the intensity of the nuclear or cytoplasmic staining (no staining, 0 ; weak 
A

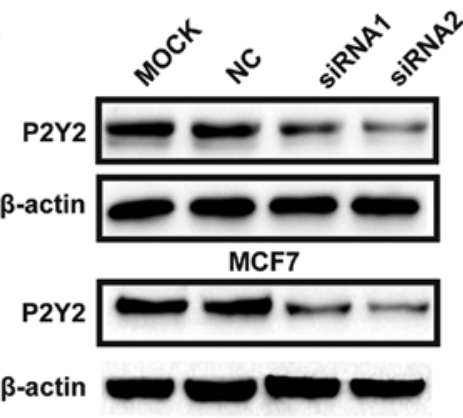

Hs578T

B
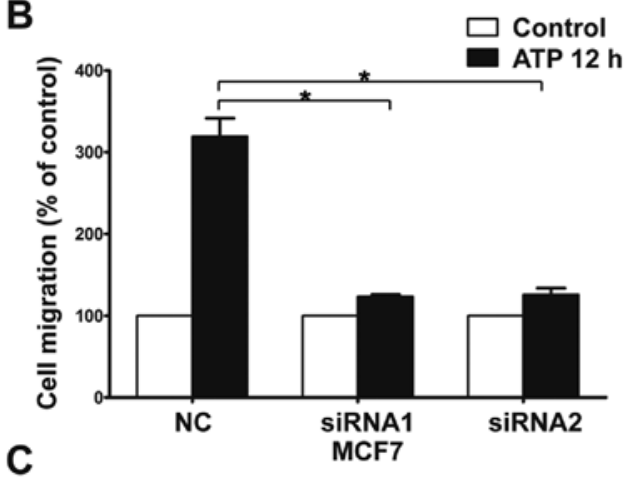

C

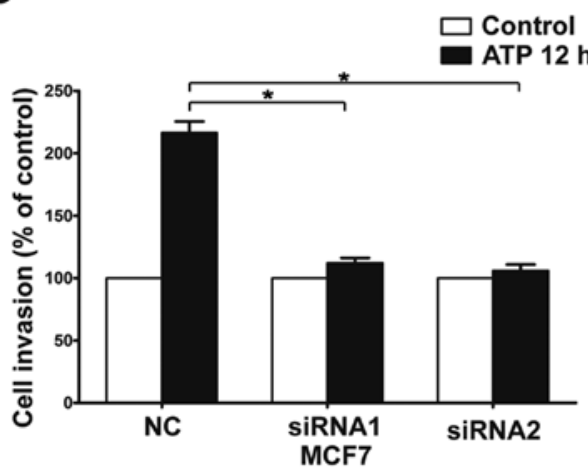

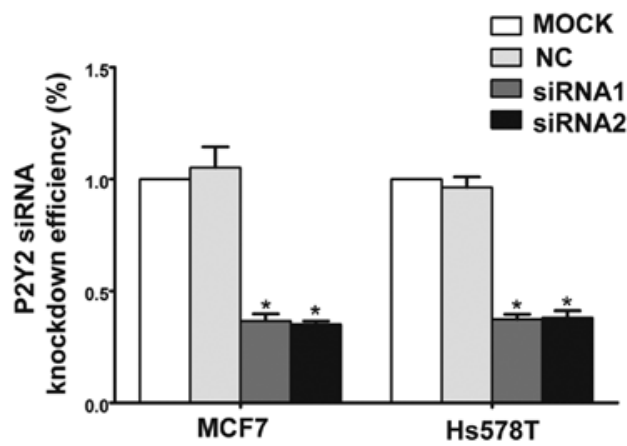
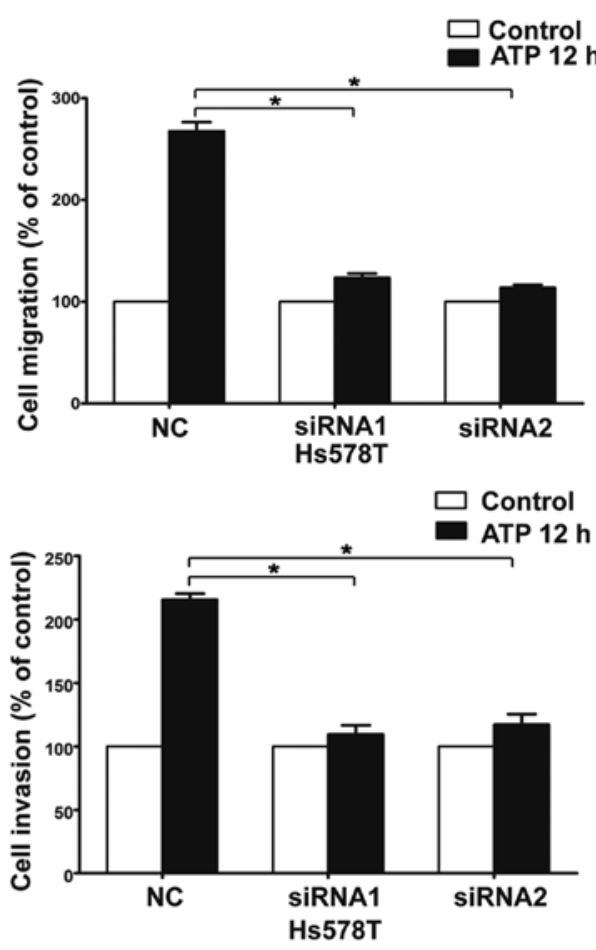

Figure 3. Effects of P2Y2 receptor knockdown on ATP-mediated migration and invasion in breast cancer cells. (A) MCF7 and Hs578T cells were transfected with two different P2Y2 siRNAs (siRNA1 and siRNA2) or a control siRNA (NC). Western blot experiments were carried out to confirm the knockdown efficiency. (B and C) In vitro migration and invasion assays were carried out as described in Materials and methods in the absence (control) or presence of $100 \mu \mathrm{M}$ ATP (ATP $12 \mathrm{~h}$ ). Data of cell migration or invasion were calculated as a percentage of the control cells. Results are demonstrated by histograms and values are presented as mean $\pm \mathrm{SD}$ (vertical bars). At least 3 independent experiments were performed; ${ }^{*} \mathrm{P}<0.05$.

staining, 1; moderate staining, 2; strong staining, 3) and the extent of stained cells $(0 \%, 0 ; 1-10 \%, 1 ; 11-50 \%, 2 ; 51-80 \%, 3$; $81-100 \%, 4)$. The final immunoreactive score was determined by multiplying the intensity and extent scores, with a minimum score of 0 and a maximum score of 12 . For each tumor, we also scored the staining intensity of invasive edge areas and the tumor core areas.

Data analysis and statistics. All experiments, except immunohistochemistry, were repeated at least 3 times. Statistical analyses were performed using SPSS software (version 18.0; SPSS, Inc., Chicago, IL, USA). Student's t-test was performed to determine whether there was a significant difference between 2 groups, and one-way ANOVA analysis was performed for comparison of multiple means. In addition, the non-parametric Spearman's rho correlation coefficient was used to analyze associations of the P2Y2 receptor expression with different clinicopathological characteristics. Statistical significance is indicated at $\mathrm{P}<0.05$.
Ethics statement. The tissue samples used in the present study were archived paraffin tissue blocks from the Department of Pathology, Peking University Third Hospital. Many of the breast cancer patients operated on before 2011 were lost to follow-up in our hospital. Written or verbal consent could not be obtained from these patients when they were integrated into the present study as an essential part. We described this circumstance to the Peking University Ethics Committee. The Ethics Committees/IRB approved that this group could be exempt from informed consent. The data/samples were used anonymously. The present study was approved by the Peking University IRB (reference no. IRB00001052-11029).

\section{Results}

P2Y2 receptor is significantly expressed in breast cancer cells. Real-time PCR analysis showed that MCF7 and Hs578T breast cancer cells predominantly expressed mRNA for P2Y1, P2Y2, P2Y4, P2Y6 and P2Y11 receptors (Fig. 1A). Of all 
A

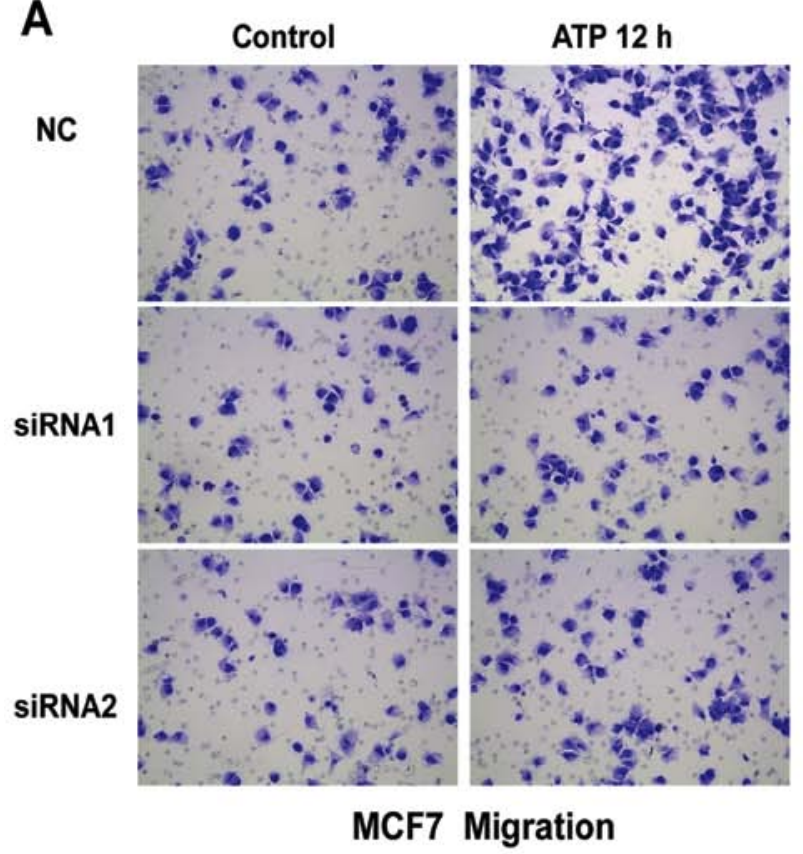

C

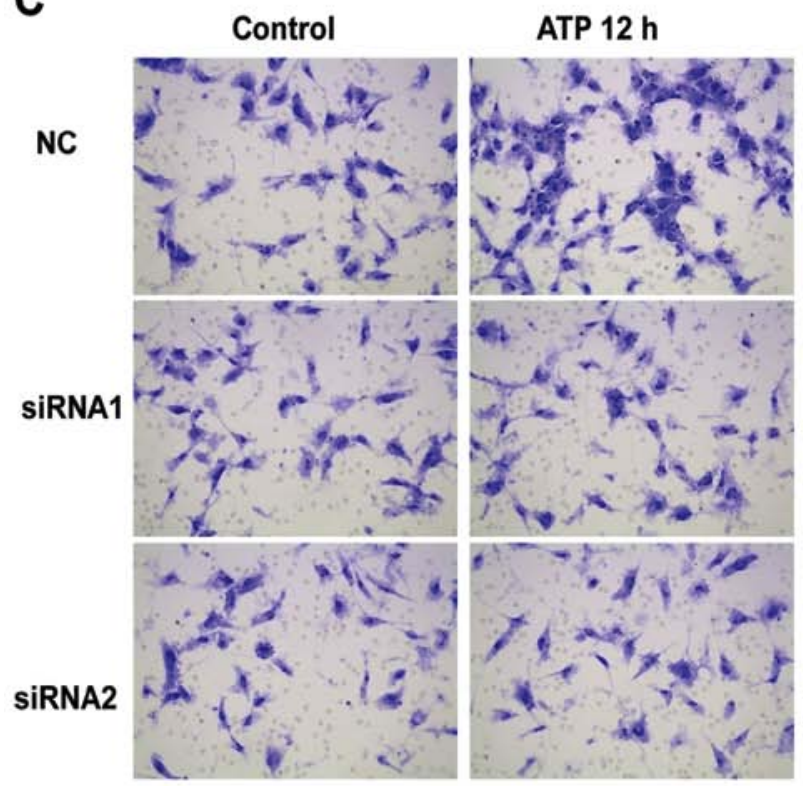

Hs578T Migration
B

NC
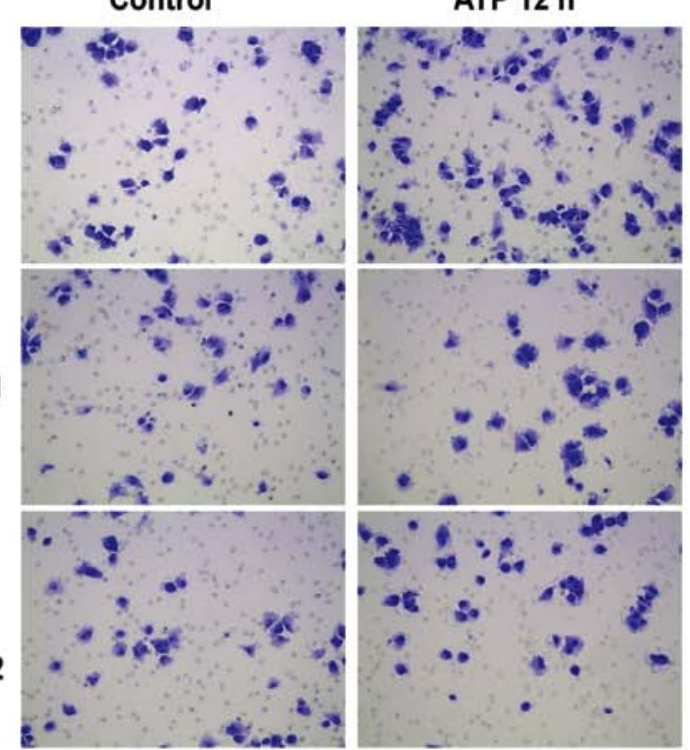

MCF7 Invasion

D

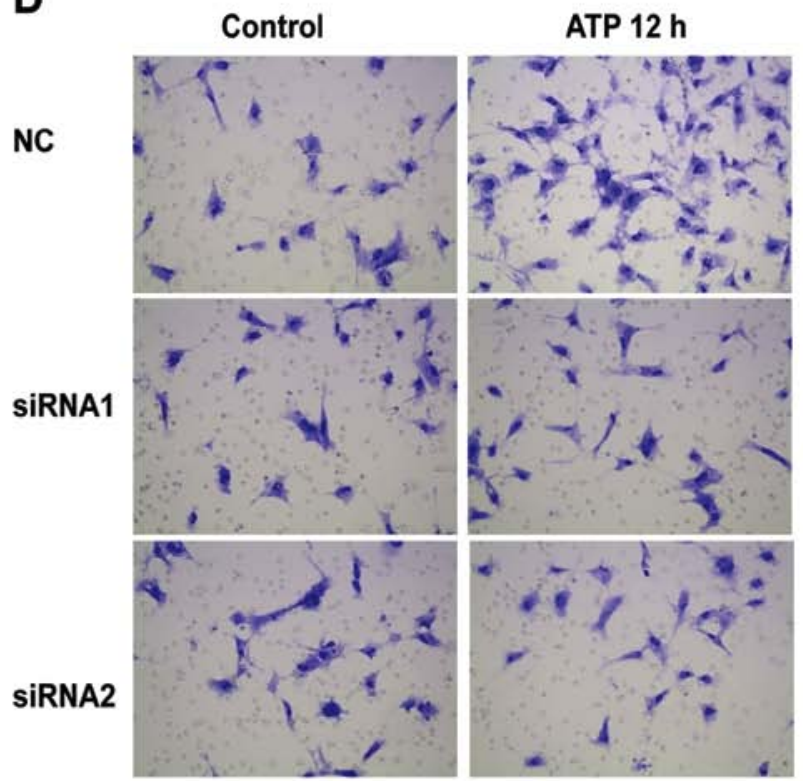

Hs578T Invasion

Figure 4. Effects of P2Y2 receptor knockdown on ATP-mediated migration and invasion in breast cancer cells. (A-D) In vitro migration and invasion assays were carried out as described in Materials and methods in the absence (control) or presence of $100 \mu$ M ATP (ATP 12 h). At least 3 independent experiments were performed.

the P2Y subtypes, the P2Y2 receptor exhibited the highest expression in both breast cancer cell lines. In addition, the protein expression of P2Y2 was examined by western blotting in breast cancer cells and immortal normal mammary cells MCF-10A. We found that P2Y2 protein was highly expressed in the MCF7 and Hs578T breast cancer cell lines compared with the MCF-10A mammary epithelial cells (Fig. 1B).

P2Y2 receptor is involved in ATP-or UTP-promoted migration and invasion of breast cancer cells. The Transwell assay revealed that ATP $(100 \mu \mathrm{M})$ promoted the migration and invasion of MCF7 and Hs578T breast cancer cells. UTP $(100 \mu \mathrm{M})$, as another preferred ligand of the P2Y2 receptor, also caused marked enhancement of migration and invasion in the breast cancer cells, which was consistent with the effect of ATP stimulus (Fig. 2A-D). Then, we used siRNAs (siRNA1 and siRNA2) to silence the expression of the $\mathrm{P} 2 \mathrm{Y} 2$ receptor in the MCF7 and Hs578T cells (Fig. 3A). Compared with the control cells, ATP-driven migration and invasion were markedly inhibited after downregulation of the $\mathrm{P} 2 \mathrm{Y} 2$ receptor (Figs. 3B and C, and 4A-D). Similarly, knockdown of the P2Y2 receptor also significantly blocked UTP-mediated migration and invasion of MCF7 and Hs578T cells (Figs. 5A and B, and 6A-D). All the above data indicate that the $\mathrm{P} 2 \mathrm{Y} 2$ receptor is involved in the regulation of migration and invasion of breast cancer cells. 
A

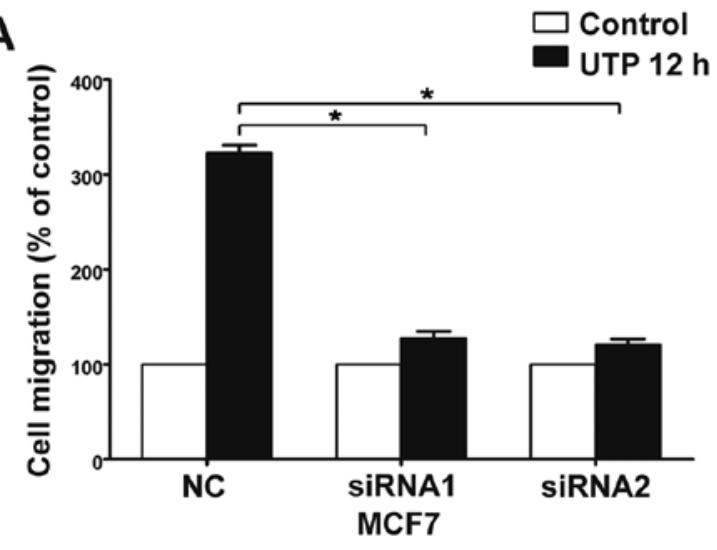

B

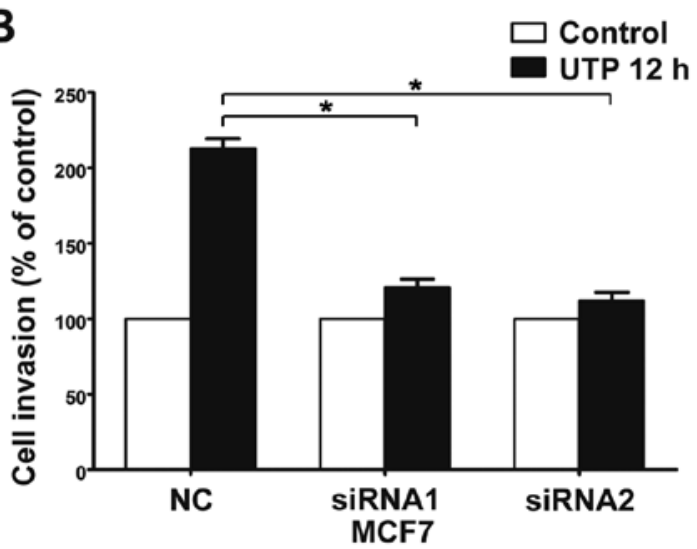

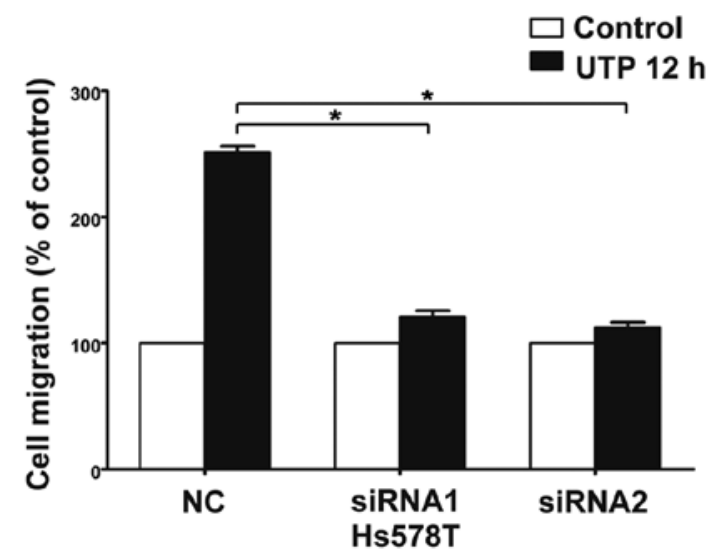

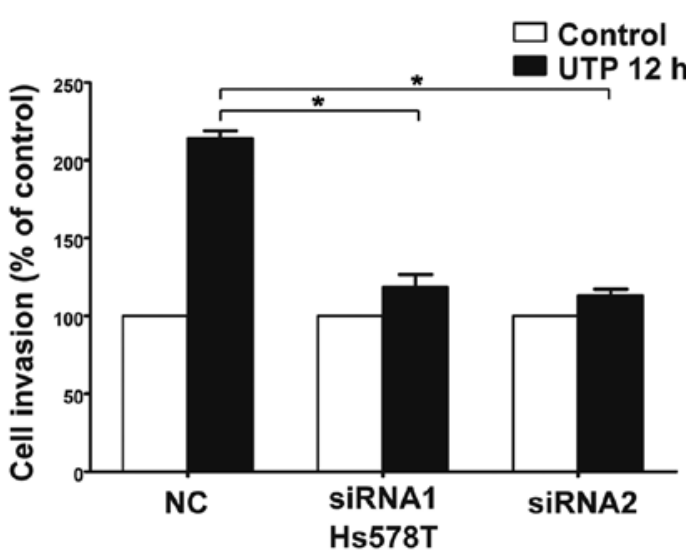

Figure 5. Effects of P2Y2 receptor knockdown on UTP-mediated migration and invasion in breast cancer cells. In vitro (A) migration and (B) invasion assays were carried out as described in Materials and methods in the absence (control) or presence of $100 \mu \mathrm{M}$ UTP (UTP $12 \mathrm{~h}$ ). Data of cell migration or invasion were calculated as a percentage of the control cells. Results are demonstrated by histograms and values are presented as mean \pm SD (vertical bars). At least 3 independent experiments were performed; ${ }^{2} \mathrm{P}<0.05$.

P2Y2 receptor mediates ATP or UTP-driven expression of EMT-related genes Snail and E-cadherin. In the presence of ATP, expression of Snail was significantly increased in the MCF7 and Hs578T cells, while expression levels of E-cadherin and claudin-1 were markedly reduced at both the mRNA and protein levels. Meanwhile, UTP exerted similar effects on the regulation of Snail and E-cadherin in the MCF7 and Hs578T cells (Figs. 7A-D, and 8A-D). Furthermore, after downregulation of the $\mathrm{P} 2 \mathrm{Y} 2$ receptor, the ATP-mediated increase in Snail expression and decrease in E-cadherin expression (Fig. 9A and B) were significantly attenuated. Similarly, knockdown of the P2Y2 receptor significantly inhibited UTP-mediated expression changes in EMT-related genes in the MCF7 and Hs578T cells (Fig. 10A and B). These data indicate that the $\mathrm{P} 2 \mathrm{Y} 2$ receptor mediates the ATP- or UTP-induced expression changes of EMT-related genes in breast cancer cells.

Expression of P2Y2, Snail and E-cadherin in invasive breast cancer specimens. Positive immunoreactivity (brown) in cytoplasm was observed for P2Y1, P2Y2, P2Y4 and P2Y6 receptors in most breast cancer cells, but not detected in the tumor-adjacent normal glandular epithelial cells. Positive P2Y2 staining could also be noted in the nuclei of some ductal myoepithelial cells (Fig. 11A). The staining of P2Y2 and P2Y6 receptors was more intensive than that of $\mathrm{P} 2 \mathrm{Y} 1$ and $\mathrm{P} 2 \mathrm{Y} 4$ receptors.
Consistent with the results from breast cancer cell lines, the P2Y2 receptor was markedly expressed in breast tumor tissues. Particularly, the expression of the $\mathrm{P} 2 \mathrm{Y} 2$ receptor was higher at the invasive edge of tumor, in infiltrating tumor cells in the breast adipose tissue and the cancer embolus in the lymphatic sinuses, than that at the tumor core areas (Fig. 11B-D).

\section{Expression levels of EMT-related genes Snail and E-cadherin} were detected in breast cancer tissues. Snail expression in the tumor cells was either nuclear, often in combination with weak-to-moderate cytoplasmic positivity, or only cytoplasmic. High Snail expression was observed at the invasive edge of tumor cells (Fig. 12A). In contrast, the intercellular borders of the normal glandular epithelial cells were strongly stained by E-cadherin. The invasive breast carcinoma cells and the myoepithelial cells of remnant ducts and ductules showed much weaker or negative staining of E-cadherin at cell-cell borders (Fig. 12B). As a pair of adverse markers of epithelial mesenchymal transition, the loss of E-cadherin expression (negative or weak) was significantly associated with the high expression of Snail $\left(\chi^{2}=41.92, \mathrm{P}<0.01\right)$. Meanwhile, we observed the increased expression of the $\mathrm{P} 2 \mathrm{Y} 2$ receptor in the invasive edge of the tumor (Fig. 11B). This indicated a possibility that upregulation of the $\mathrm{P} 2 \mathrm{Y} 2$ receptor coexisted with an increase in Snail or a reduction in E-cadherin, but a statistical correlation was not found. 
A

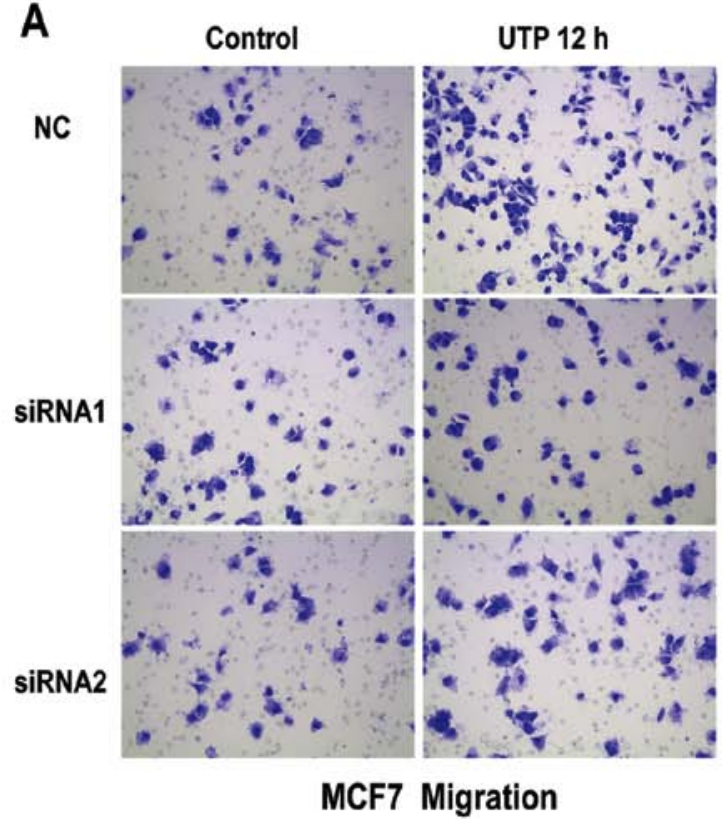

C

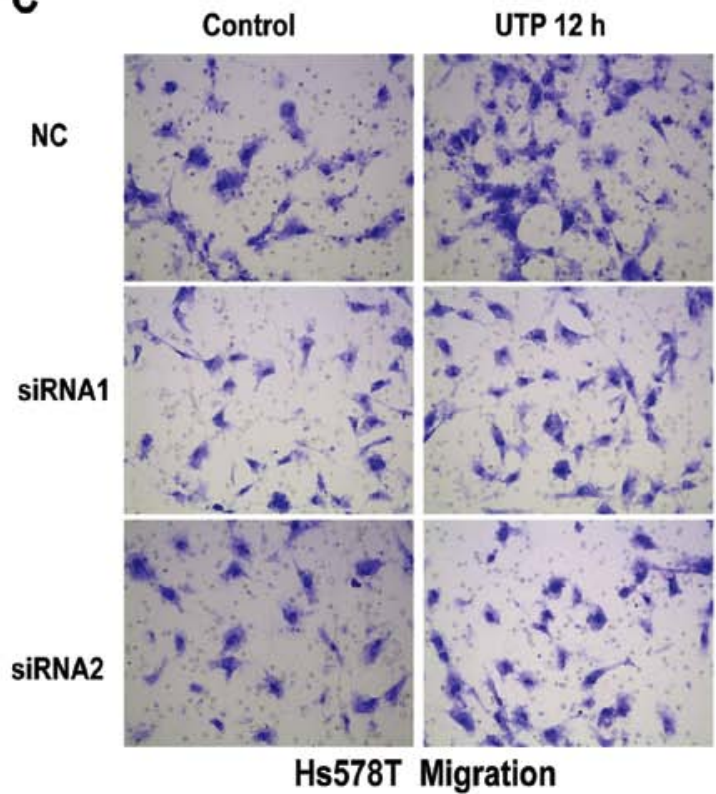

B

NC

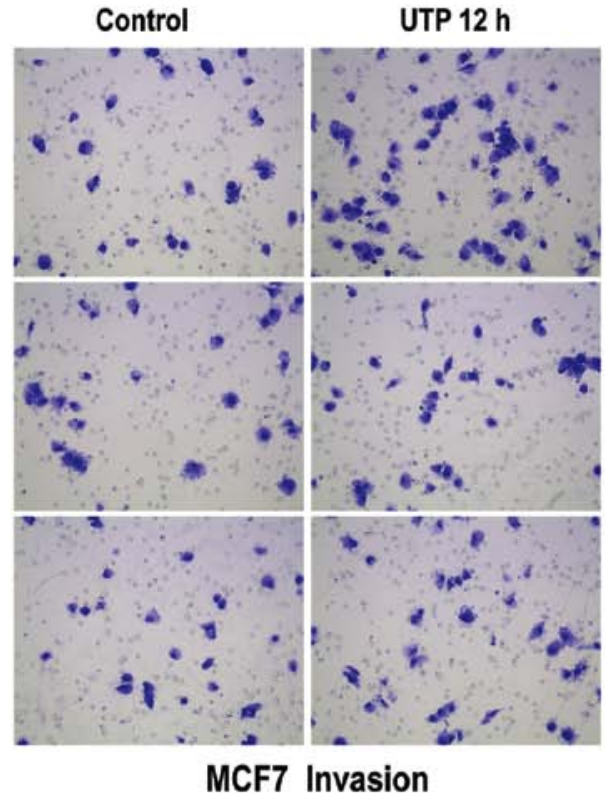

D

NC

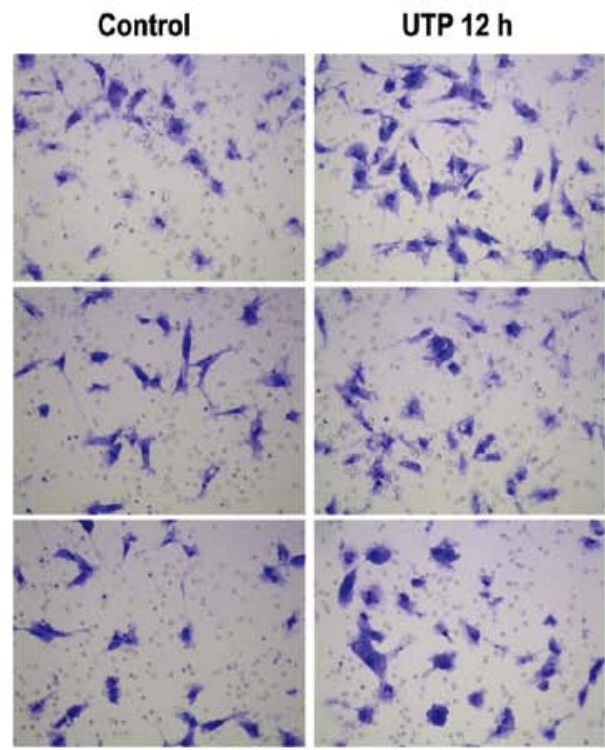

Hs578T Invasion

Figure 6. Effects of P2Y2 receptor knockdown on UTP-mediated migration and invasion in breast cancer cells. (A-D) In vitro migration and invasion assays were carried out as described in Materials and methods in the absence (control) or presence of $100 \mu \mathrm{M}$ UTP (UTP 12 h). At least 3 independent experiments were performed.

Association of P2Y2 receptor with clinicopathological parameters of breast cancer. Finally, the associations between expression of $\mathrm{P} 2 \mathrm{Y} 2$ receptor and some clinicopathological characteristics were analyzed (Table I). We found that the expression level of the P2Y2 receptor was negatively correlated with histological grade $(\mathrm{P}=0.023)$. It was notable that the immunostaining of the $\mathrm{P} 2 \mathrm{Y} 2$ receptor was decreased in tumors with higher grade. Furthermore, P2Y2 receptor expression was significantly higher in the tumors with lower Ki-67 index ( $r=-0.161, P=0.026)$ and no HER2 amplification $(\mathrm{P}=0.008)$. It is possible that $\mathrm{P} 2 \mathrm{Y} 2$ plays adverse roles in the malignant proliferation and invasion of breast cancer. We found no significant correlation between P2Y2 receptor expression and various other clinical characteristics such as nodule status, distant metastasis, clinical stage, as well as NPI grouping.

\section{Discussion}

In the present study, we demonstrated that activation of the P2Y2 receptor enhanced breast cancer cell invasiveness by induction of EMT. The P2Y2 receptor was found to be highly expressed in MCF-7 and Hs578T cells. In addition, the migratory and invasive capacities of the breast cancer cells were markedly increased under stimulation of the $\mathrm{P} 2 \mathrm{Y} 2$ receptor. We also identified in breast cancer tissues that the P2Y2 receptor was abundantly expressed at the invasive edge of the tumor, in infiltrating tumor cells in the breast adipose tissue 

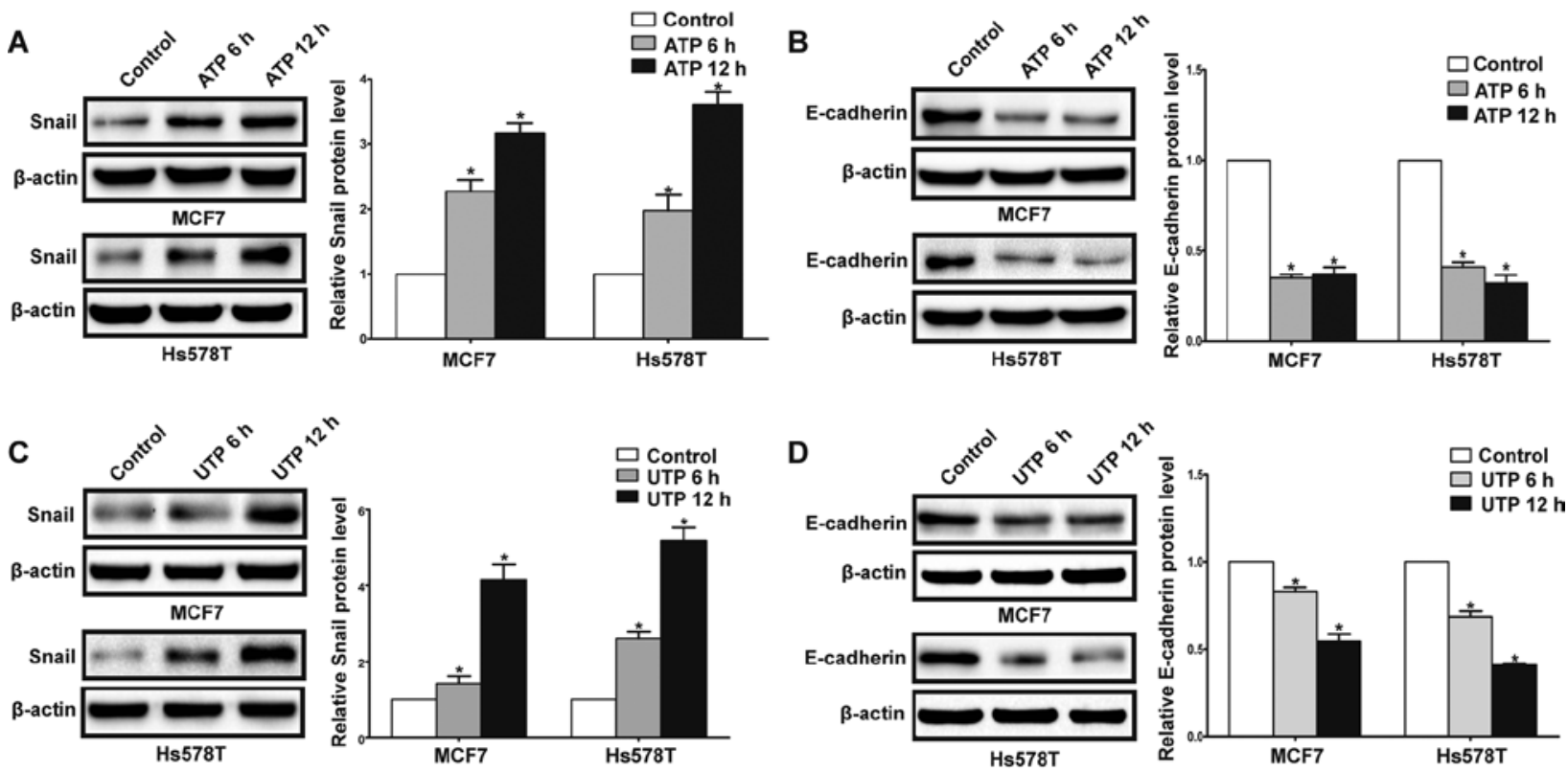

Figure 7. Extracellular ATP or UTP regulates the expression of EMT-related genes in breast cancer cells. MCF7 and Hs578T breast cancer cells were treated in the absence (control) or in presence of $100 \mu \mathrm{M} \mathrm{ATP} / 100 \mu \mathrm{M}$ UTP for 6 and $12 \mathrm{~h}$. Protein levels of (A and C) Snail and (B and D) E-cadherin were examined by western blot analysis. Expressions of these proteins were normalized to their respective expression in the control cells (without ATP or UTP). Data are presented as mean $\pm \mathrm{SD}$ (vertical bars). At least 3 independent experiments were performed; ${ }^{*} \mathrm{P}<0.05$.
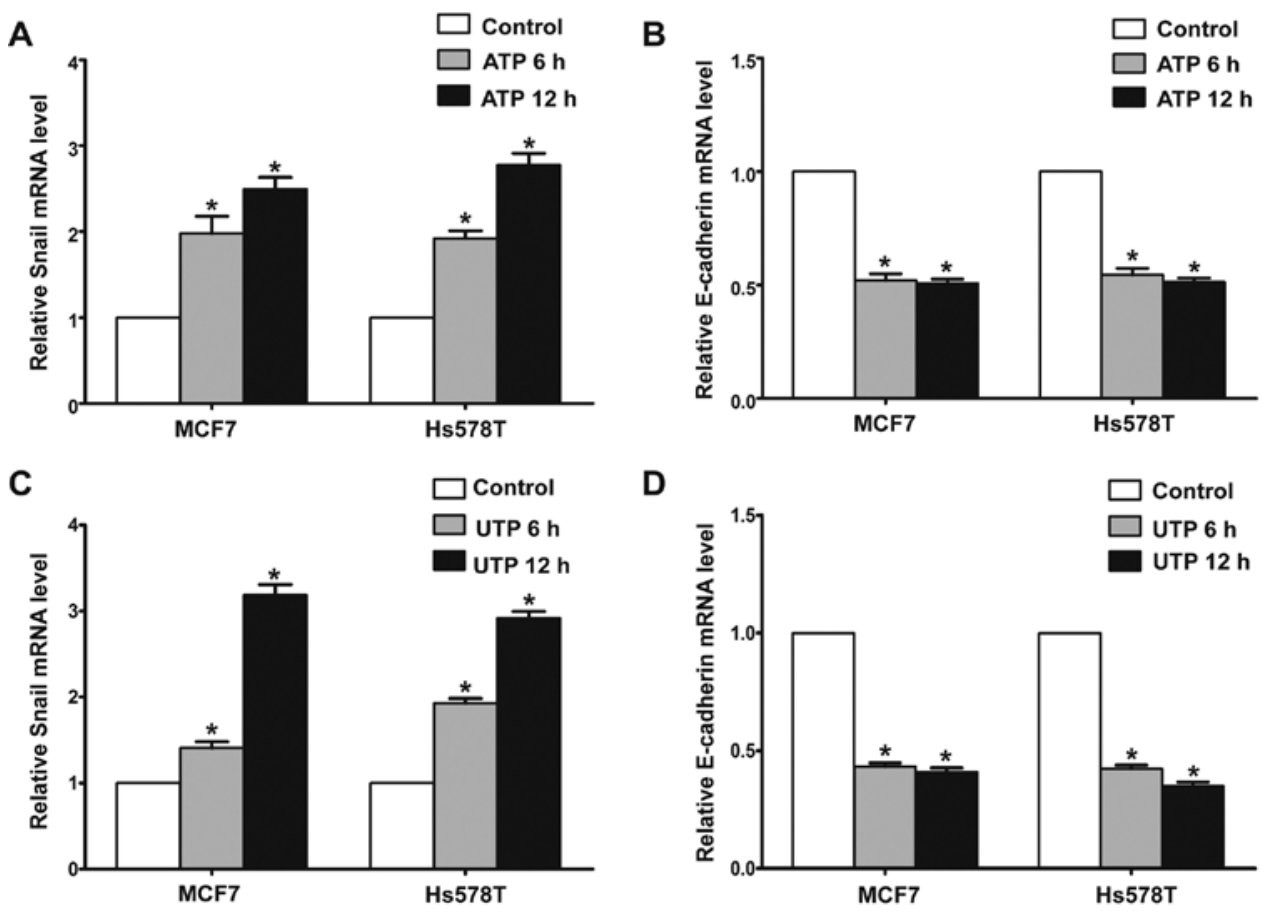

D

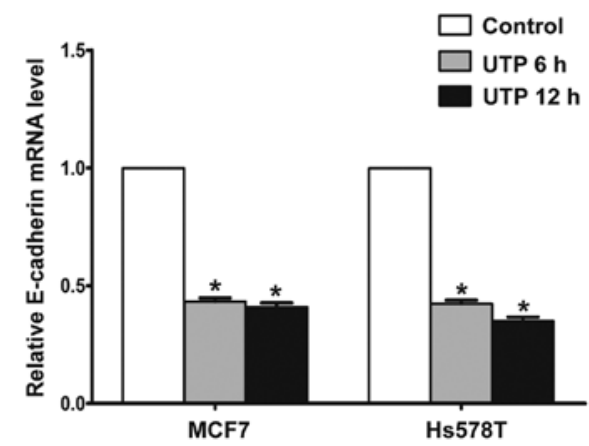

Figure 8. Extracellular ATP or UTP regulates the expression of EMT-related genes in breast cancer cells. MCF7 and Hs578T breast cancer cells were treated in the absence (control) or in presence of $100 \mu \mathrm{M} \mathrm{ATP} / 100 \mu \mathrm{M}$ UTP for 6 and $12 \mathrm{~h}$. The mRNA levels of (A and C) Snail and (B and D) E-cadherin were examined by real-time PCR analysis. Results are demonstrated by histograms to quantify the expression levels. Data are presented as mean \pm SD (vertical bars). At least 3 independent experiments were performed; ${ }^{*} \mathrm{P}<0.05$.

or the cancer embolus in the lymphatic sinuses compared to the tumor core. In addition, high expression of Snail and weak or negative expression of E-cadherin were observed at the invasive edge of the tumor.

Extracellular ATP exerts diverse effects on a variety of tissues and cell types via specific purinergic receptors, consisting of P2X and P2Y families (7). Among these P2Y receptor subtypes, the $\mathrm{P} 2 \mathrm{Y} 2$ receptor displays distinct effects on progression of different types of cancer. In the present study, we showed that the P2Y2 receptor was highly expressed in MCF-7 and Hs578T breast cancer cell lines. Notably, in normal breast tissue, the $\mathrm{P} 2 \mathrm{Y} 2$ receptor was expressed in the 
A

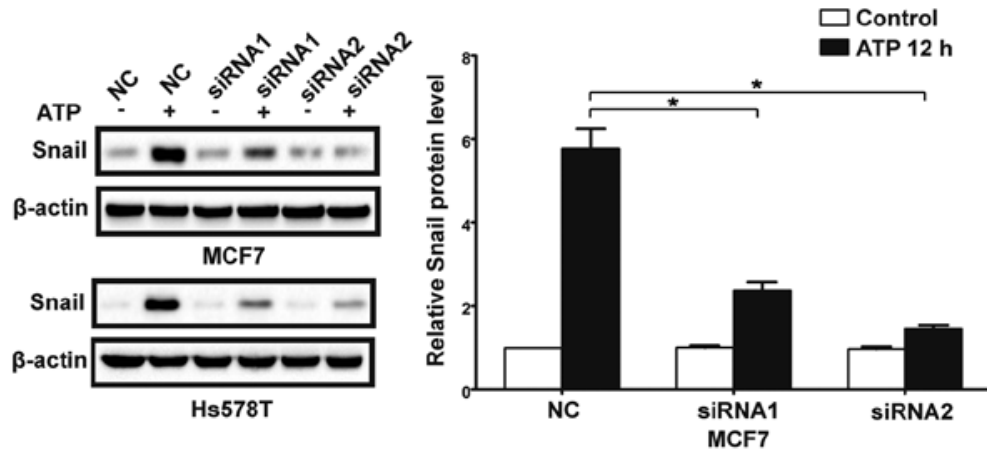

B
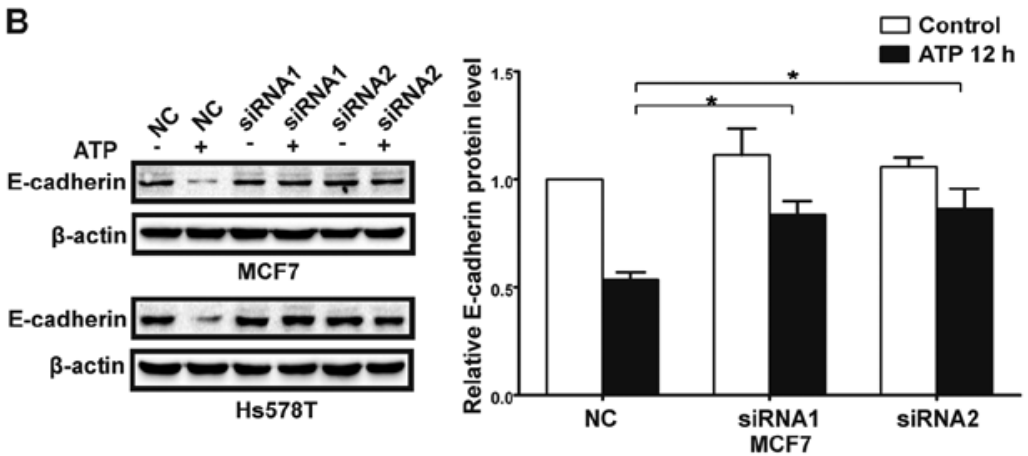
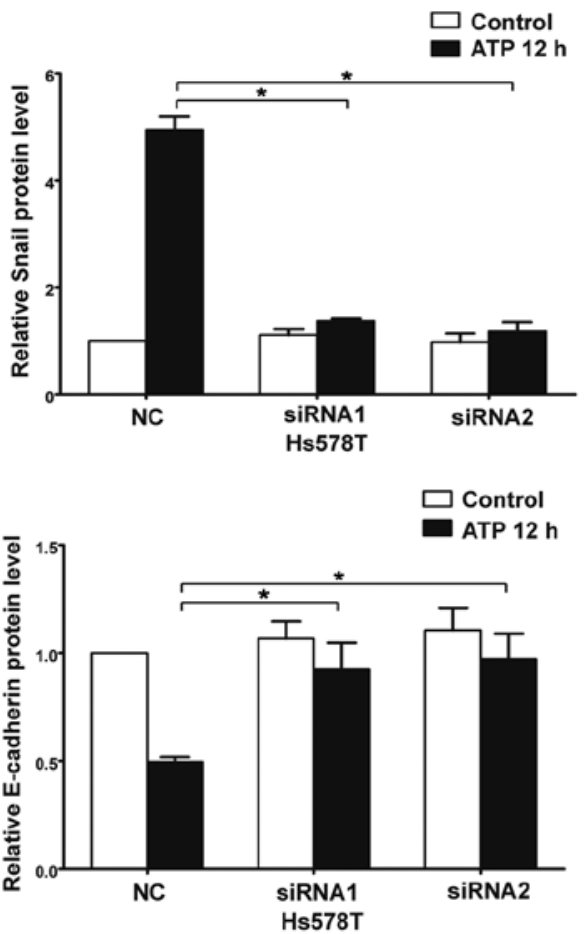

Figure 9. Knockdown of the P2Y2 receptor attenuates ATP-induced expression changes in EMT-related genes in breast cancer cells. P2Y2-silenced cells (siRNA1 and siRNA2) and control siRNA cells (NC) were treated with or without $100 \mu \mathrm{M}$ ATP for $12 \mathrm{~h}$ (ATP $12 \mathrm{~h}$ ). Western blot experiments were performed to examine protein levels of (A) Snail and (B) E-cadherin. Expression levels of these proteins were normalized to their respective expression in the control cells (without ATP). Data are presented as mean $\pm \mathrm{SD}$ (vertical bars). At least 3 independent experiments were performed; * $\mathrm{P}<0.05$.

A
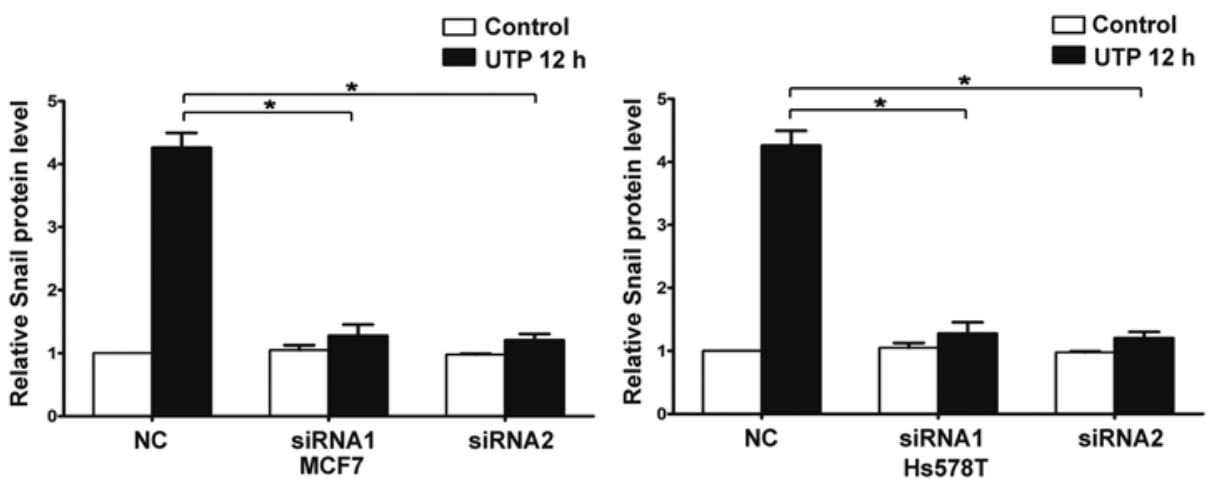

B
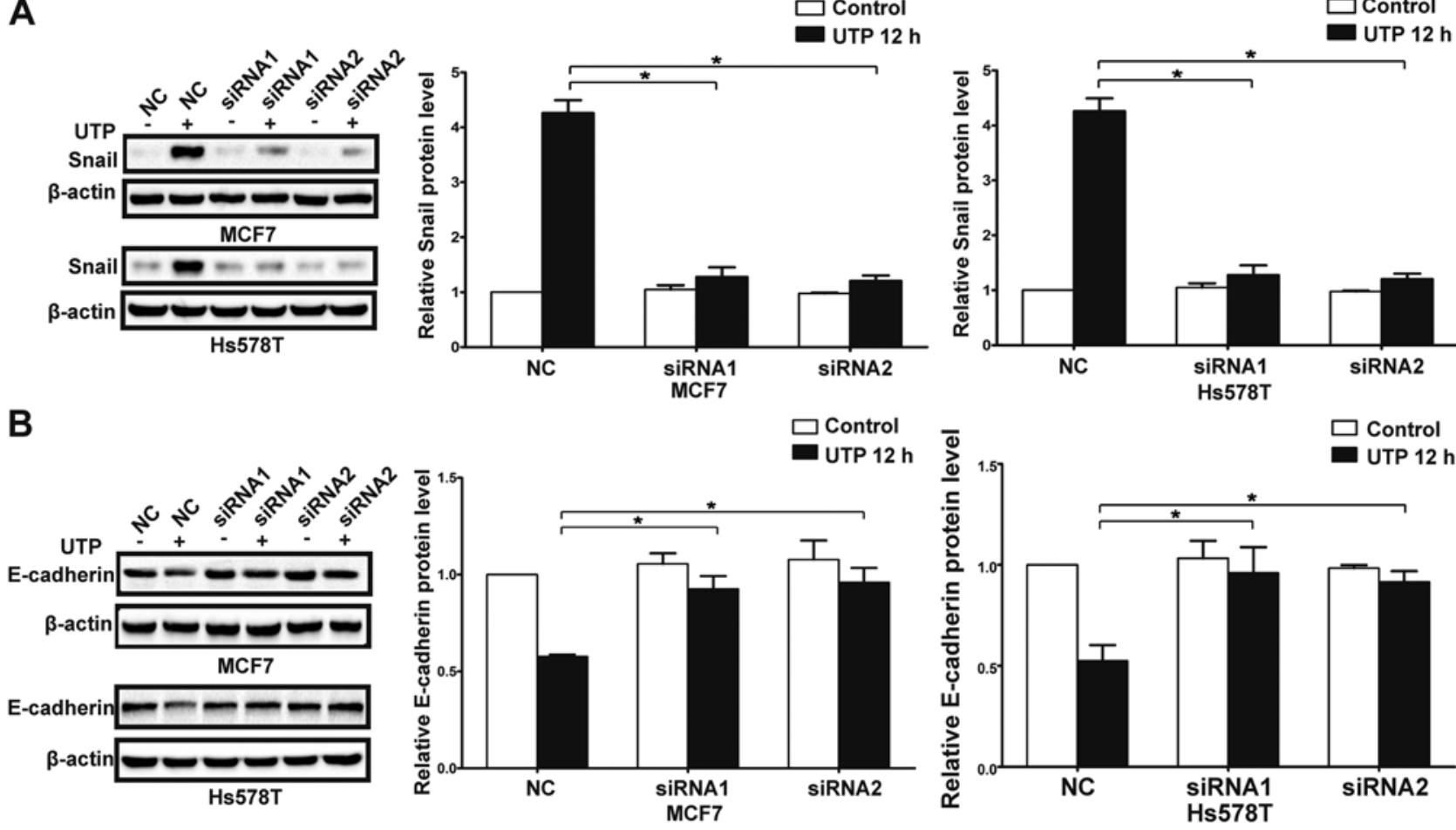

Figure 10. Knockdown of the P2Y2 receptor attenuates UTP-induced expression changes in EMT-related genes in breast cancer cells. P2Y2-silenced cells (siRNA1 and siRNA2) and control siRNA cells (NC) were treated with or without $100 \mu \mathrm{M}$ UTP for $12 \mathrm{~h}$ (UTP $12 \mathrm{~h}$ ). Western blot experiments were performed to examine protein levels of (A) Snail and (B) E-cadherin. Expression levels of these proteins were normalized to their respective expression in the control cells (without UTP). Data are presented as mean \pm SD (vertical bars). At least 3 independent experiments were performed; * $\mathrm{P}<0.05$.

ductal myoepithelial cells with nuclear staining pattern, but not in the glandular epithelial cells of breast lobules. However, in the breast cancer tissues, we found that expression of the P2Y2 receptor in the tumor cells was significantly higher than 

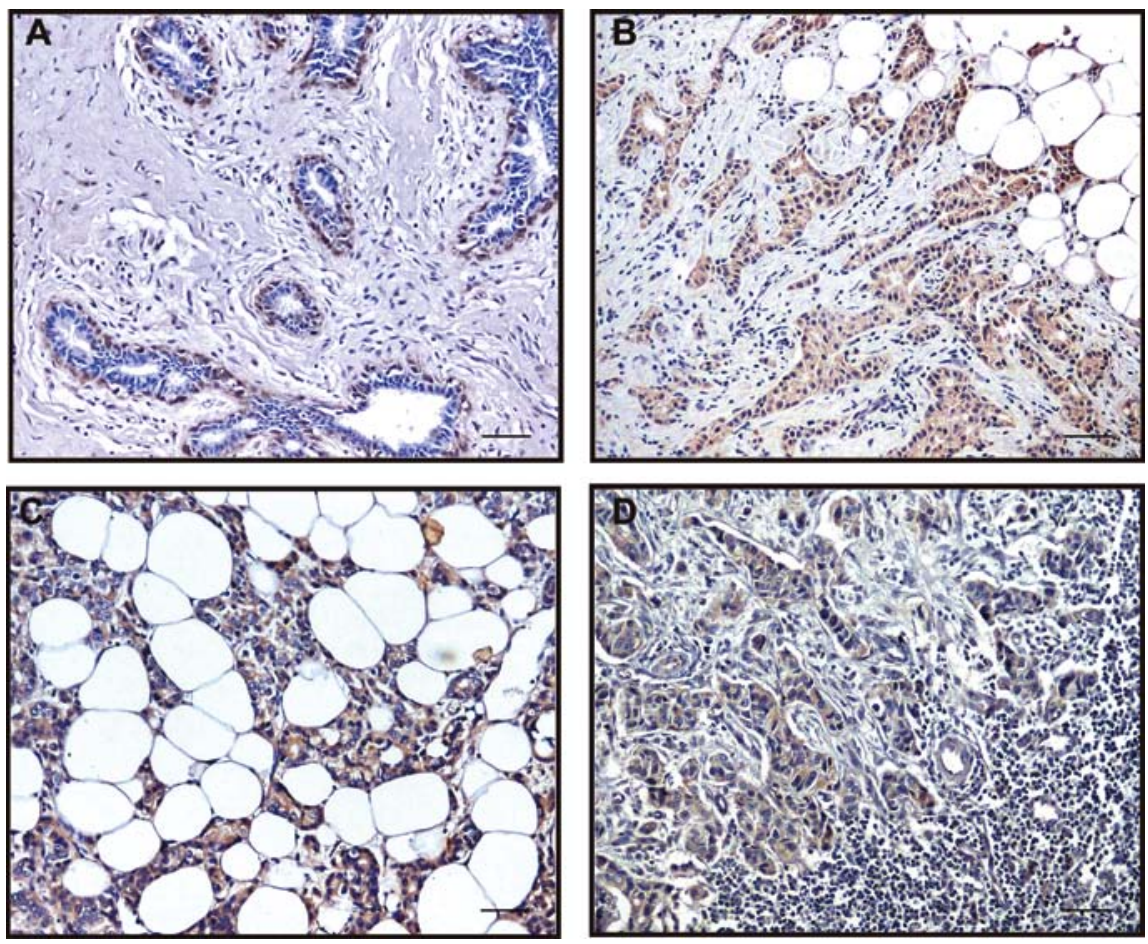

Figure 11. Positive staining of the P2Y2 receptor in normal tumor-adjacent breast and breast cancer tissues. In normal tumor-adjacent breast tissues, nuclear staining of the P2Y2 receptor was observed in various ductal myoepithelial cells (A, magnification, x200). In the breast tumor tissues, relative overexpression of the P2Y2 receptor was noted at the invasive edge of the tumor (B, magnification, $\mathrm{x} 200)$, in infiltrating tumor cells in the breast adipose tissue (C, magnification, $\mathrm{x} 200$ ) or the cancer embolus in the lymphatic sinuses (D, magnification, $\mathrm{x} 200$ ) compared to the tumor core. Scale bars, $50 \mu \mathrm{m}$.
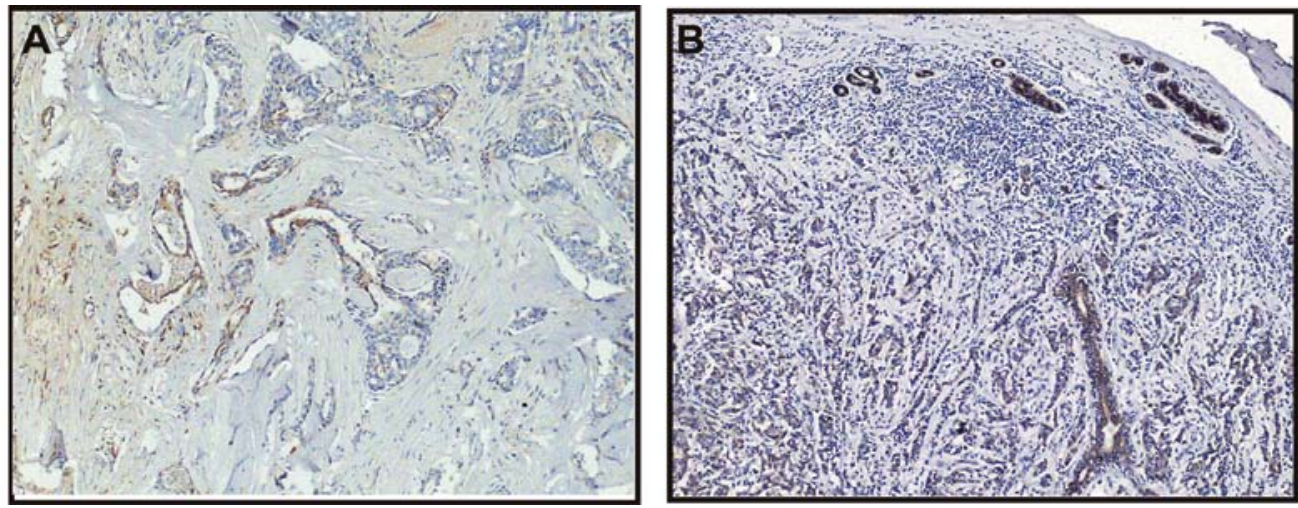

Figure 12. Immunostaining of Snail and E-cadherin in the tissue sections of breast carcinoma. (A) Representative case of increased positive Snail staining in the invasive edge of the tumor (magnification, x100). (B) Reduced and heterogeneous staining for E-cadherin was observed in the poorly differentiated breast carcinoma cells, while the normal luminal cells of the terminal ductules exhibit strong cytoplasmic membrane (linear intercellular) immunoreactivity for E-cadherin (magnification, x100). Scale bars, $100 \mu \mathrm{m}$.

that in the tumor-adjacent normal lobules. It has been reported that a high concentration of ATP, as an agonist of the P2Y2 receptor, was observed at tumor sites (4). ATP can be released from infiltrating inflammatory cells as well as from the tumor cells via different mechanisms, such as granule exocytosis, plasma membrane channels, or cell lysis. Therefore, P2Y2 receptor expression may be a sequential event due to the elevated extracellular ATP in the microenvironment of breast cancer.

Some researchers have reported that activation of the P2Y2 receptor promoted cell proliferation in melanoma and lung cancer cells $(22,23)$. On the contrary, the P2Y2 receptor inhibited cell proliferation of esophageal cancer and some type of colorectal cancer $(24,25)$. Our previous studies demonstrated that ATP promoted migration, invasion and metastasis of prostate cancer cells, while it inhibited cell growth $(10,11,26,27)$. In the present study, we found that the P2Y2 receptor expression was negatively correlated with histological grade, HER2 amplification and Ki67 index of breast cancer, which indicated that the P2Y2 receptor may participate in the inhibition of tumor proliferation.

Various studies strongly suggest that ATP is a crucial microenvironmental element in driving metastatic spread (28). Schumacher et al pinpointed the nucleotide as an endothelia relaxant, facilitating tumor cell escape (29). Particularly, ATP release was inevitable in the borderline of the tumor nest as a 
result of tissue destruction and disintegration of inflammatory cells. Jelassi et al identified ATP as a mediator of tumor infiltration (30). In the present study, the P2Y2 receptor mediated ATP-promoted migration and invasion of breast cancer cells in vitro. Similarly, Chadet et al demonstrated that activation of the $\mathrm{P} 2 \mathrm{Y} 2$ receptor increased MCF-7 breast cancer cell migration through the MEK-ERK1/2 signaling pathway (31). In breast cancer tissues, we also observed a relative overexpression of the $\mathrm{P} 2 \mathrm{Y} 2$ receptor at the invasive edge of the tumor, in infiltrating tumor cells in the breast adipose tissue or the cancer embolus in the lymphatic sinuses compared to the tumor core. These data strongly suggest that the $\mathrm{P} 2 \mathrm{Y} 2$ receptor is a key receptor mediating the migration and invasion of breast cancer.

The tumor microenvironment plays a pivotal role in tumor cell proliferation, survival and migration. Signals from the tumor microenvironment could trigger cancer cells to adopt an invasive phenotype through EMT, which is thought to promote cancer cell progression and invasion into the surrounding microenvironment. It is a multi-step process in which cells acquire molecular alterations that facilitate dysfunctional cell-cell adhesive interactions, loss of cell-cell junctions, and reorganization of the cytoskeleton, all of which result in the loss of epithelial characteristics and the acquisition of a more spindle-shaped morphology defined as 'transient mesenchymal conversion' $(2,32,33)$. EMT is typically characterized by the loss of intercellular adhesion and polarity, downregulation of epithelial markers, upregulation of mesenchymal markers and acquisition of increased motility, invasiveness and metastatic capabilities (2). The full accomplishment of EMT requires a complex genetic programme that is partially mediated by a number of specific transcription factors, such as Snail, Slug and Twist. These factors are expressed in a variety of cell types and modulate directly or indirectly the expression of a great number of genes involved in invasion and metastasis of cancer (34). It has been reported that ATP participates in the EGF-induced EMT process in breast cancer cells (35). Our previous studies demonstrated that ATP induced EMT in prostate cancer cells $(11,26)$. In the present study, we found that extracellular ATP led to significant upregulation of Snail and marked downregulation of E-cadherin and claudin-1 in breast cancer cells in vitro. After knockdown of the P2Y2 receptor, the changes in the expression of ATP-induced EMT-related genes were markedly inhibited, indicating that the P2Y2 receptor participates in ATP-induced EMT in breast cancer cells. Davis et al demonstrated that induction of EMT in breast cancer cells is calcium signal dependent. However, it was reported that ATP modulated intracellular $\mathrm{Ca}^{2+}$ by activation of P2Y2 and $\mathrm{P} 2 \mathrm{Y} 4$ receptors in MCF7 cells (36). Therefore, it is possible that activation of the $\mathrm{P} 2 \mathrm{Y} 2$ receptor induces EMT via the calcium signaling pathway in breast cancer cells. Several studies provide support for the presence of EMT markers in invasive breast cancer, particularly in the invasion-metastasis cascade $(32,37)$. Sarrió et al demonstrated that EMT-like changes occur preferentially in the basal subtype of breast carcinomas with high aggressiveness and metastatic capabilities (32). Similarly, Snail was found to be expressed in all the infiltrating ductal carcinomas (IDC) presenting lymph node metastasis and its expression was found to be inversely correlated with the grade of differentiation of breast tumors (38). As for the breast cancer tissues in the present study, while the intercellular borders of the tumor-adjacent normal glandular structures present in breast carcinoma specimens were strongly stained by E-cadherin, the invasive breast carcinoma cells showed much weaker or negative staining at the cell-cell borders. Nevertheless, Snail was highly expressed at the invasive edge of breast tumor tissue next to the breast adipose tissue, where the elevated expression of the P2Y2 receptor was also observed. Collectively, these results indicate that extracellular ATP may induce EMT at the invasive edge via activation of the $\mathrm{P} 2 \mathrm{Y} 2$ receptor. Additionally, it was reported that $\mathrm{P} 2 \mathrm{Y}$ receptors participate in $\mathrm{TGF} \beta$-induced EMT of MDCK cells (39). Our previous study also showed that the P2Y2 receptor mediated ATP-induced EMT in prostate cancer cells (11). However, we did not find any association between the expression of the P2Y2 receptor and E-cadherin or Snail protein in breast cancer tissues, which could be due to the complex microenvironment of invasive breast cancer. Nevertheless, all these data suggest the important role of the P2Y2 receptor in mediating ATP-induced EMT in breast cancer.

In conclusion, the present study demonstrated that the P2Y2 receptor was critical for mediating ATP-promoted migration and invasion as well as ATP-driven expression changes in EMT-related genes Snail and E-cadherin. The critical role of the $\mathrm{P} 2 \mathrm{Y} 2$ receptor indicates it could be a potential therapeutic target for the treatment of breast cancer. However, there are multiple P2Y receptor subtypes expressed in breast cancer cells, and the contribution of other receptor subtypes in ATP-mediated progression of breast cancer cannot be fully excluded. Investigation of the detailed molecular mechanisms of purinergic signaling in the progression of breast cancer may still be our focus in future research.

\section{Acknowledgements}

We thank all the individuals who participated in the present study. The present study was supported by grants to W.-G.F. from the National Natural Science Foundation of China (81621063).

\section{References}

1. Siegel R, Ma J, Zou Z and Jemal A: Cancer statistics, 2014. CA Cancer J Clin 64: 9-29, 2014.

2. Thiery JP: Epithelial-mesenchymal transitions in tumour progression. Nat Rev Cancer 2: 442-454, 2002.

3. Murata Y, Yasuo T, Yoshida R, Obata K, Yanagawa Y, Margolskee RF and Ninomiya Y: Action potential-enhanced ATP release from taste cells through hemichannels. J Neurophysiol 104: 896-901, 2010.

4. Pellegatti P, Raffaghello L, Bianchi G, Piccardi F, Pistoia V and Di Virgilio F: Increased level of extracellular ATP at tumor sites: In vivo imaging with plasma membrane luciferase. PLoS One 3: e2599, 2008.

5. Wang X, Arcuino G, Takano T, Lin J, Peng WG, Wan P, Li P, Xu Q, Liu QS, Goldman SA, et al: P2X7 receptor inhibition improves recovery after spinal cord injury. Nat Med 10: 821-827, 2004.

6. Raffaghello L, Chiozzi P, Falzoni S, Di Virgilio F and Pistoia V: The $\mathrm{P} 2 \mathrm{X}_{7}$ receptor sustains the growth of human neuroblastoma cells through a substance P-dependent mechanism. Cancer Res 66: 907-914, 2006.

7. Di Virgilio F: Purines, purinergic receptors, and cancer. Cancer Res 72: 5441-5447, 2012.

8. Stagg J and Smyth MJ: Extracellular adenosine triphosphate and adenosine in cancer. Oncogene 29: 5346-5358, 2010. 
9. Chen L, He HY, Li HM, Zheng J, Heng WJ, You JF and Fang WG: ERK1/2 and p38 pathways are required for P2Y receptor-mediated prostate cancer invasion. Cancer Lett 215 239-247, 2004

10. Zhang Y, Gong LH, Zhang HQ, Du Q, You JF, Tian XX and Fang WG: Extracellular ATP enhances in vitro invasion of prostate cancer cells by activating Rho GTPase and upregulating MMPs expression. Cancer Lett 293: 189-197, 2010.

11. Li WH, Qiu Y, Zhang HQ, Liu Y, You JF, Tian XX and Fang WG: $\mathrm{P} 2 \mathrm{Y} 2$ receptor promotes cell invasion and metastasis in prostate cancer cells. Br J Cancer 109: 1666-1675, 2013.

12. Liu J,LiaoZ, Camden J, Griffin KD, Garrad RC, Santiago-PérezLI, González FA, Seye CI, Weisman GA and Erb L: Src homology 3 binding sites in the $\mathrm{P} 2 \mathrm{Y}_{2}$ nucleotide receptor interact with Src and regulate activities of Src, proline-rich tyrosine kinase 2, and growth factor receptors. J Biol Chem 279: 8212-8218, 2004.

13. Tu MT, Luo SF, Wang CC, Chien CS, Chiu CT, Lin CC and Yang CM: $\mathrm{P} 2 \mathrm{Y}_{2}$ receptor-mediated proliferation of $\mathrm{C}_{6}$ glioma cells via activation of Ras/Raf/MEK/MAPK pathway. Br J Pharmacol 129: 1481-1489, 2000.

14. Muscella A, Elia MG, Greco S, Storelli C and Marsigliante S: Activation of $\mathrm{P} 2 \mathrm{Y} 2$ receptor induces c-FOS protein through a pathway involving mitogen-activated protein kinases and phosphoinositide 3-kinases in HeLa cells. J Cell Physiol 195: 234-240, 2003.

15. Nylund G, Hultman L, Nordgren S and Delbro DS: P2 $Y_{2-}$ and $\mathrm{P}_{2} \mathrm{Y}_{4}$ purinergic receptors are over-expressed in human colon cancer. Auton Autacoid Pharmacol 27: 79-84, 2007.

16. Künzli BM, Bernlochner MI, Rath S, Käser S, Csizmadia E, Enjyoji K, Cowan P, d'Apice A, Dwyer K, Rosenberg R, et al: Impact of CD39 and purinergic signalling on the growth and metastasis of colorectal cancer. Purinergic Signal 7: 231-241, 2011.

17. Early Breast Cancer Trialists' Collaborative Group (EBCTCG): Effects of chemotherapy and hormonal therapy for early breast cancer on recurrence and 15-year survival: An overview of the randomised trials. Lancet 365: 1687-1717, 2005.

18. Blamey RW, Ellis IO, Pinder SE, Lee AH, Macmillan RD, Morgan DA, Robertson JF, Mitchell MJ, Ball GR, Haybittle JL, et al: Survival of invasive breast cancer according to the Nottingham Prognostic Index in cases diagnosed in 1990-1999. Eur J Cancer 43: 1548-1555, 2007.

19. Schmittgen TD and Livak KJ: Analyzing real-time PCR data by the comparative C(T) method. Nat Protoc 3: 1101-1108, 2008.

20. Albini A, Iwamoto Y, Kleinman HK, Martin GR, Aaronson SA, Kozlowski JM and McEwan RN: A rapid in vitro assay for quantitating the invasive potential of tumor cells. Cancer Res 47: 3239-3245, 1987.

21. Matos LL, Stabenow E, Tavares MR, Ferraz AR, Capelozzi VL and Pinhal MA: Immunohistochemistry quantification by a digital computer-assisted method compared to semiquantitative analysis. Clinics 61: 417-424, 2006.

22. Schafer R, Sedehizade F, Welte T and Reiser G: ATP- and UTP-activated P2Y receptors differently regulate proliferation of human lung epithelial tumor cells. Am J Physiol Lung Cell Mol Physiol 285: L376-L385, 2003.

23. White N, Ryten M, Clayton E, Butler P and Burnstock G: P2Y purinergic receptors regulate the growth of human melanomas. Cancer Lett 224: 81-91, 2005.

24. Maaser K, Höpfner M, Kap H, Sutter AP, Barthel B, von Lampe B, Zeitz $\mathrm{M}$ and Scherübl H: Extracellular nucleotides inhibit growth of human oesophageal cancer cells via $\mathrm{P}_{2} \mathrm{Y}_{2}$-receptors. Br J Cancer 86: 636-644, 2002.
25. Höpfner M, Maaser K, Barthel B, von Lampe B, Hanski C, Riecken EO, Zeitz $M$ and Scherübl H: Growth inhibition and apoptosis induced by $\mathrm{P} 2 \mathrm{Y} 2$ receptors in human colorectal carcinoma cells: Involvement of intracellular calcium and cyclic adenosine monophosphate. Int J Colorectal Dis 16: 154-166, 2001.

26. Qiu Y, Li WH, Zhang HQ, Liu Y, Tian XX and Fang WG: P2X7 mediates ATP-driven invasiveness in prostate cancer cells. PLoS One 9: e114371, 2014.

27. Fang WG, Pirnia F, Bang YJ, Myers CE and Trepel JB: $\mathrm{P} 2$-purinergic receptor agonists inhibit the growth of androgenindependent prostate carcinoma cells. J Clin Invest 89: 191-196, 1992.

28. Adinolfi E: New intriguing roles of ATP and its receptors in promoting tumor metastasis: Presented by Maria P. Abbracchio. Purinergic Signal 9: 487-490, 2013.

29. Schumacher D, Strilic B, Sivaraj KK, Wettschureck N and Offermanns S: Platelet-derived nucleotides promote tumor-cell transendothelial migration and metastasis via $\mathrm{P} 2 \mathrm{Y} 2$ receptor. Cancer Cell 24: 130-137, 2013.

30. Jelassi B, Anchelin M, Chamouton J, Cayuela ML, Clarysse L, Li J, Goré J, Jiang LH and Roger S: Anthraquinone emodin inhibits human cancer cell invasiveness by antagonizing P2X7 receptors. Carcinogenesis 34: 1487-1496, 2013.

31. Chadet S, Jelassi B, Wannous R, Angoulvant D, Chevalier S, Besson $\mathrm{P}$ and Roger $\mathrm{S}$ : The activation of $\mathrm{P} 2 \mathrm{Y} 2$ receptors increases MCF-7 breast cancer cells migration through the MEK-ERK1/2 signalling pathway. Carcinogenesis 35: 1238-1247, 2014.

32. Sarrió D, Rodriguez-Pinilla SM, Hardisson D, Cano A, Moreno-Bueno G and Palacios J: Epithelial-mesenchymal transition in breast cancer relates to the basal-like phenotype. Cancer Res 68: 989-997, 2008.

33. Trimboli AJ, Fukino K, de Bruin A, Wei G, Shen L, Tanner SM, Creasap N, Rosol TJ, Robinson ML, Eng C, et al: Direct evidence for epithelial-mesenchymal transitions in breast cancer. Cancer Res 68: 937-945, 2008.

34. Lee JM, Dedhar S, Kalluri R and Thompson EW: The epithelialmesenchymal transition: New insights in signaling, development, and disease. J Cell Biol 172: 973-981, 2006.

35. Davis FM, Kenny PA, Soo ET, van Denderen BJ, Thompson EW, Cabot PJ, Parat MO, Roberts-Thomson SJ and Monteith GR: Remodeling of purinergic receptor-mediated $\mathrm{Ca}^{2+}$ signaling as a consequence of EGF-induced epithelial-mesenchymal transition in breast cancer cells. PLoS One 6: e23464, 2011.

36. Scodelaro Bilbao P, Boland R, Russo de Boland A and Santillán G: ATP modulation of mitogen activated protein kinases and intracellular $\mathrm{Ca}^{2+}$ in breast cancer (MCF-7) cells Arch Biochem Biophys 466: 15-23, 2007.

37. Ma L, Teruya-Feldstein J and Weinberg RA: Tumour invasion and metastasis initiated by microRNA-10b in breast cancer. Nature 449: 682-688, 2007.

38. Blanco MJ, Moreno-Bueno G, Sarrio D, Locascio A, Cano A, Palacios J and Nieto MA: Correlation of Snail expression with histological grade and lymph node status in breast carcinomas. Oncogene 21: 3241-3246, 2002.

39. Wolff CI, Bundey RA and Insel PA: Involvement of P2Y receptors in TGF $\beta$-induced EMT of MDCK cells. FASEB J 22: 942-945, 2008

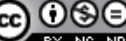

This work is licensed under a Creative Commons Attribution-NonCommercial-NoDerivatives 4.0 International (CC BY-NC-ND 4.0) License. 